\title{
IAMJ
}

INTERNATIONAL

AYURVEDIC

MEDICAL JOURNAL

\section{TO STUDY THE ROLE OF SHWASKUTHAR RASA IN COVID-19 INFECTION: A CONCEPTUAL STUDY}

\author{
Swapnil Mundhe ${ }^{1}$, Preetam Itnar ${ }^{2}$, Kalyani Jadhav ${ }^{3}$ \\ ${ }^{1} \mathrm{PG}$ Rasashastra and Bhaishajya Kalpana, ${ }^{2} \mathrm{Guide},{ }^{3} \mathrm{HOD}$ of Rasashastra \\ MAM's Sumatibhai Shah Ayurveda Mahavidya, Hadpsar, Pune - 411028, Maharashtra, India
}

Corresponding Author: swapnilmundhe2@gmail.com

https://doi.org/10.46607/iamj3509122021

(Published Online: December 2021)

Open Access

(C) International Ayurvedic Medical Journal, India

Article Received: 27/11//2021 - Peer Reviewed: 29/11/2021 - Accepted for Publication 30/11/2021

Check for updates

\begin{abstract}
Background: Common symptoms of COVID-19 include fever, cough, fatigue, shortness of breath, and loss of smell and taste. While the majority of cases result in mild symptoms, some progress to acute respiratory distress syndrome (ARDS) likely precipitated by a cytokine storm, multi-organ failure, septic shock, and blood clots. Most of the drugs of SARS- COVID contain higher generation antibiotics, Antiviral drugs, Steroidal drugs which further leads to respiratory complication like respiratory distress, fibrosis of lungs, COPDS whereas Ayurvedic drugs heal the lungs without causing any post covid complications. So, the need of an hour is to use and assess the Ayurvedic formulation in SARS-COVID. Aim \& Objectives: To study the role of Shwaskuthar ras in covid-19 and to explore the concept of Shwaskuthar Rasa from various Granthas. Materials \& Methods: Collected from various Granthas, Samhita, Article, Pubmed, google scholar and Journals. Shwaskuthar rasa is a well-known combination of Ayurvedic text used in respiratory disorders.
\end{abstract}

Keywords: COVID-19, Granthas, Rasa Aushadhi, Shwaskuthar

\section{INTRODUCTION}

The severe acute respiratory syndrome coronavirus 2 (SARS-CoV-2) leading to the novel coronavirus disease 2019 (COVID-19) has a rapid human to human transmission of the virus through droplet infection and aerosols. The time from exposure to onset of symptoms is typically around five days but may range from two to fourteen days. ${ }^{1}$ One infected case of COVID-19 on average infects 3 new cases, the reproductive number (R0) being 3 for SARS$\mathrm{CoV}-2$. Since this is a novel viral infection in humans, antiviral drugs, and vaccines have not yet been developed for this illness. Thus, the major emphasis is on social distancing, hand wash, and facemask. $^{2}$

Fever (Jwara) is well understood in Ayurveda, and it occupies the first chapter in treatment (Chikitsa) in 
two of the canonical texts of Ayurveda, namely Charaka Samhita and Ashtanga Hridayam. It deals with diagnosis (Nidanam), pathophysiology (Samprapti), classification, management, medicines, diet and prognosis.

From the Ayurvedic point of view, COVID -19 is a Janapadodhwamsa vikara (epidemic disease). The concept of an epidemic is described in Charaka Samhita: Vimana Sthana, Chapter 3 even though there is dissimilarity in the physical constitution of human beings, still there are such factors that are common to all individuals and vitiation of these factors leads to the simultaneous manifestation of diseases having the same set of symptoms leading to the destruction of countries. Factors that are common for all the inhabitants of a country are air, water, location and seasons. Vimana Sthana, Janapadodhwamsa is a situation where the environment - air, water, land and seasons - is vitiated, causing a simultaneous manifestation of disease among large populations (epidemic), destroying human habitations. ${ }^{4}$

Shwaskuthar rasa a reputed preparation of Ayurveda valued for the treatment of Shwasa and Kasa (asthma and allergy) is a herb mineral formulation that contains herbs, purified Aconitum Ferox (Aconite), Piper longum (long pepper), Piper nigrum (black pepper), and Zingiber officinale (ginger), and minerals that is, Parada (mercury), Gandhaka (sulphur), Tankana (borax), and Manahsila (arsenic disulphide) in purified form as per Ayurvedic text. ${ }^{5}$ A. Ferox inhibited the biosynthesis of leukotriene B4 in bovine polymorphonuclear leukocytes. ${ }^{6} P$. longum have a traditional claim of Ayurveda for antiallergic and antiasthmatic activity. ${ }^{7} P$. nigrum suppressed and reduced the infiltration of eosinophils, hyper responsiveness, and inflammation in mice. ${ }^{8}$

Z. officinale are capable of inhibiting allergic reactions and is useful for the treatment and prevention of allergic diseases. ${ }^{9}$ Review of literature revealed that Shwaskuthar rasa, apart from treating asthma and allergy, is used for the cure of cough, laryngitis, tuberculosis, unconsciousness. ${ }^{10}$

\begin{tabular}{|l|l|l|}
\hline Sr. No. & Ingredients & Parts \\
\hline 1 & Aconitum Ferox & 1 \\
\hline 2 & Piper longum & 1 \\
\hline 3 & Piper nigrum & 1 \\
\hline 4 & Zingiber officinale & 1 \\
\hline 5 & Parad & 1 \\
\hline 6 & Gandhak & 1 \\
\hline 7 & Tankana & 1 \\
\hline 8 & Manahsila & 1 \\
\hline
\end{tabular}

\section{MATERIAL AND METHOD:}

1. Textbooks, granthas related to shwaskuthar rasa.

2. Journals, articles related to covid-19 and shwaskuthar rasa.

3. To analyses and comprehend.

SIGNIFICANCE OF RASA AUSHADHI: The Rasa Aushadhis (Metallic and Mineral medicines) are known for their smaller dosage. They do not cause any nauseating sensation during consumption. These medicines provide quick and good results, and they are useful in treating severe diseases. ${ }^{11}$

Before reaching the management of COVID-19 from Rasa Aushadhi, we must discuss the possible Samprapti of this disease.

\section{POSSIBLE SAMPRAPTI OF COVID-19:}

According to the symptoms and effect on the body, possible Samprapti of COVID-19 is decided as:

\begin{tabular}{|l|l|}
\hline $\begin{array}{l}\text { Roga Bheda } \\
\text { (Type of } \\
\text { Disease) }\end{array}$ & $\begin{array}{l}\text { Vishanu janya (Viral) Sannipataja } \\
\text { Shwasnak Jwara (Kapha-vata-pitta } \\
\text { anubandhi) }\end{array}$ \\
\hline Symptoms & $\begin{array}{l}\text { Fever, dry cough, tiredness, aches and } \\
\text { pains, sore throat, diarrhoea, } \\
\text { conjunctivitis, headache, loss of taste } \\
\text { or smell, a rash on the skin, or } \\
\text { discolouration of fingers or toes, } \\
\text { difficulty breathing or shortness of } \\
\text { breath, chest pain or pressure, loss of } \\
\text { speech or movement }\end{array}$ \\
\hline Dosha & $\begin{array}{l}\text { Tridoshaj (kapha-vata pradhan } \\
\text { pittanubandhi) Kaphaavrit vata }\end{array}$ \\
\hline Dushya & $\begin{array}{l}\text { Rasa dhatu; all other dhatu are also } \\
\text { affected by the severity }\end{array}$ \\
\hline Strotasa & \begin{tabular}{l} 
Praanvaha Strotas \\
\hline
\end{tabular} \\
\hline
\end{tabular}

\section{PREPARATION OF SHWAS KUTHAR RASA}

Shwas Kuthar rasa prepared using herbal and mineral ingredients as prescribed in Ayurvedic text, initially detoxifying the Parada (mercury), 
Manahsila (arsenic disulfide), Gandhaka (sulfur), Tankana (borax), and A. ferox (Vastanabha) as per given Ayurvedic text. Equal quantities of Shodhit (detoxified and pure) Parada and Gandhaka were taken $(1: 1)$ in a stone mortar in reference amount, triturated for $40 \mathrm{~h}$ or until it attained the required Kajjalabha (blackish appearance) and Nishchandra (lusterless) state, that is, shining of Parada is lost. This state of the formulation is called Kajjali. Kajjali was then triturated, with the reference amount of powdered Manahsila, Vastanabha, Tankana, and Trikatu (equal part of black pepper, long pepper, and ginger), for $72 \mathrm{~h}$ to obtain fine powdered herbs mineral formulation Shwas Kuthar rasa and it was allowed for drying and stored in a glass jar. ${ }^{12}$

\section{DISCUSSION}

Why Shwasa Kuthar rasa: Khalveeya Rasayana is the most commonly used preparation as they are easily prepared by mixing herbal and mineral drugs in specified proportions as shown above. Shwasa Kuthar rasa is a commonly prescribed Khalveeya Rasayana indicated in different conditions of Shwasa.

In Ayurveda, it may be defined as Aupsargika roga/Samsara roga (communicable disease). The disease which is communicable due to a history of contact with a person who has affected tuberculosis),

Netrabhishyanda (conjunctivitis) etc. are communicable from one person to another. In Ayurveda, a disturbance to the regulation of body temperature is called Jwara, which is correlated to the medical concept of fever. Fever as a disease is classified into eight categories: Vata, Pitta, Kapha, Vata-Pitta, VataKapha, Pitta-Kapha, Vata-PittaKapha, and Aghantuja. COVID-19 illnesses are fever, cough, and fatigue, while other symptoms include sputum production, headache, hemoptysis, diarrhoea, dyspnea, and lymphopenia. ${ }^{13,14}$

Shwasakuthara Rasa acts on Tamaka Shwasa due to the action of its ingredients which directly act on Pranavaha Srotas. Most of the ingredients are VataKaphashamaka and mainly Kapha-Nihsaraka with Laghu, Ruksha and Ushna Guna, which means it mainly acts on Agnimandhya and breaks the Kapha Dosha Pradhan Samprapti. Its role is limited as it increases the hotness in many patients which was also observed in this study. Shwasa Kuthar Rasa acts through all its ingredients. Black pepper is a major constituent, it stimulates the mucous membrane of the respiratory system. It helps in mucous drainage and imparts strength to the alveolar mucous membrane. Aconitum ferox is antispasmodic in nature, hot and stimulant for mucous membrane. Shunthi and Pippali release the sputum. Manshilla absorbs excessive secretion from the alveoli. Purified Borax is antispasmodic and removes Kapha. For better Rasayana and relieving effect, treatment for a longer duration is required as the disease is chronic and incurable in nature. ${ }^{15}$

\section{CONCLUSION}

As covid-19 is a rising problem in the world now, from the above discussion it can be concluded that Shwas Kuthar rasa might be important in reducing symptoms related to Covid-19.

\section{REFERENCES}

1. https://en.wikipedia.org/wiki/Coronavirus_disease_2 019 (20 August 2021. 02:14pm)

2 https://www.who.int/healthtopics/coronavirus\#tab=tab_2 (20 August 2021 . 02:25pm)

3. https://www.ncbi.nlm.nih.gov/pmc/articles/PMC7303 645/ (21 August 2021. 01:20pm)

4. https://www.ncbi.nlm.nih.gov/pmc/articles/PMC7303 645/ (21 August 2021. 01:26pm)

5. Mishra S. 1st ed. Varanasi: Chaukhamba Surbharati Prakashan; 2005. Bhaishajya Ratnavali. [Google Scholar]

6. Kumar S, Ziereis K, Wiegrebe W, Müller K. Medicinal plants from Nepal: Evaluation as inhibitors of leukotriene biosynthesis. J Ethnopharmacol. 2000;70:191- [PubMed] [Google Scholar]

7. Banga S, Garg L, Atal C. Effects of piperine and crude extracts of Piper longum on the ciliary movements. Indian J Pharm. 1964;26:139. [Google Scholar]

8. Kim SH, Lee YC. Piperine inhibits eosinophil infiltration and airway hyperresponsiveness by suppressing $\mathrm{T}$ cell activity and Th2 cytokine production in the ovalbumin-induced asthma model. J Pharm Pharmacol. 2009;61:353- [PubMed] [Google Scholar]

9. Chen BH, Wu PY, Chen KM, Fu TF, Wang HM, Chen CY. Antiallergic potential on RBL-2H3 cells of some phenolic constituents of Zingiber officinale (ginger) $\mathrm{J}$ Nat Prod. 2009; 72:950-3. [PubMed] [Google Scholar] 
10. Janadri S, Mishra AP, Kumar R, Shanmukh I, Rao N, Kharya M. Preparation and characterization of mercury-based traditional herbomineral formulation: Shwas kuthar rasa. J Ayurveda Integr Med. 2015;6(4):268- 272. doi:10.4103/0975-9476.172383

11. Dr Ravindra Angadi, A textbook of Rasa Shastra, edition 2017, Chaukhamba surbharati Prakashan, page no. 11

12. Janadri S, Mishra AP, Kumar R, Shanmukh I, Rao N, Kharya M. Preparation and characterization of mercury-based traditional herbomineral formulation: Shwas kuthar rasa. J Ayurveda Integr Med. 2015;6(4):268- 272. doi:10.4103/0975-9476.172383

13. Rajput DS, Evolution, Ayurveda, immunity, and preventive aspects for emerging infectious diseases such as COVID-19. Int. J. Res. Pharm. Sci., 2020, 11(SPL) (1), 86-93.

14. Charak Samhita of Agnivesh elaborated by Charak \& Dridhabala, with Ayurveda Dipika Commentary, by Chakrapanidatta, edited by Jadavji Trikamji Acharya, Vimansthan, 5th Chapter, 7th verse, Page 250, Chaukhamba Surbharati Prakashan, Varanasi, Reprinted 2005

15. Rajnik Jadhav, Alankruta Dave and Jitendra Varsakiya, A CLINICAL STUDY OF SHWASKUTHAR RASA IN THE MANAGEMENT OF TAMAKA SHWASA W.S.R. TO BRONCHIAL ASTHMA, World Journal of Pharmaceutical Research, DOI: 10.20959/wjpr201813-12737.

\section{Source of Support: Nil \\ Conflict of Interest: None Declared}

How to cite this URL: SwapnilMundhe et al: To Study The Role Of Shaskuthar Rasa In Covid-19 Infection: A ConceptualStudy. International Ayurvedic Medical Journal \{online\} 2021 \{cited December 2021\} Available from: http://www.iamj.in/posts/images/upload/3139_3142.pdf 